\title{
Application of Group Psychological Counseling in Mental Health Education of College Freshmen
}

\author{
Xueying Zhang \\ School of General Education \\ Heihe University \\ Heihe, China
}

\author{
Xishun Wang \\ Student Affairs Department \\ Heihe University \\ Heihe, China
}

\author{
Lian Liu \\ Student Affairs Department \\ Heihe University \\ Heihe, China
}

\begin{abstract}
Mental health education of college students is the important task of strengthening and improving college students' ideological and political education, and an important measure to cultivate qualified talents. Freshmen form a special group, who has experienced a nine-year compulsory education and basic education in high school, and then entered into college for new and professional learning. In order to find a more positive and effective way for students' mental health education, this study attempts to conduct group psychological counseling among freshmen with the ideas of positive psychology as guidance in the form of group psychological counseling, to help students adjust to college life as soon as possible and improve their mental health. The practice and study show that, the group psychological counseling from the perspective of positive psychology plays a positive role in promoting students' mental health and various qualities.
\end{abstract}

Keywords-positive psychology; group psychological counseling; mental health

\section{INTRODUCTION}

Mental health education of college students is the important task of strengthening and improving college students' ideological and political education, and an important measure to cultivate qualified talents. Freshmen form a special group, who has experienced a nine-year compulsory education and basic education in high school, and then entered into college for new and professional learning. Freshmen need to face the changed living environment. Many students receive much concern in high school from teachers and parents. Yet, after they have entered into college, environment has changed, and the classmates are all excellent. Their original advantage no longer exists, collision appears in their self-awareness, it is easy for them to produce psychological imbalance, and there may be some problems in adaptation. The learning style has changed, as great difference exists between college and high school in terms of learning content, form and method. In

Fund project: Project of Heilongiang Planning Office of Educational Science of "Research on Freshmen's Mental Health Education under the Perspective of Positive Psychology" (Project code: GBC1211090); special project of education and student work in Heilongjiang province of "Research on Application of Group Mental Training in Mental Health Education of Freshmen" (Project code: 1253xs209). college, students are no longer restrained by the content and quantity to be learned, and the method and time of learning, what is need is their consciousness. The sudden changes make students unable to adapt to, and are easy to cause some psychological problems. The interpersonal environment has changed, as most students are away from their home, relatives and best friends. Facing the new environment, freshmen are in an urgent need for new friends and they long for emotion communication. But freshmen are still in the stage of personality mature and development, so they still will encounter some communication in distress and still encounter some troubles and psychological problems.

\section{BACKGROUND OF THE SUBJECT}

It can be found in the actual education and teaching that it is very important for college students' learning and development during college years if they can overcome their own deficiencies and adapt to college life. The mental health education of freshmen appears to be particularly important. The original mental health education mode takes mental health course as the main channel, and opens the compulsory course of mental health for freshmen comprehensively; mental health test checks the students with abnormal performance, and pay attention to students with abnormal performance and conduct interviews, as well as carry out group psychological counseling for students in need. We can find through practice that, in the original mental health education mode, classroom teaching can widely publicize mental health-related knowledge. The combination of mental health test and critical focus will improve part of the students' mental health. Group psychological counseling has effectively enhanced the efficiency of mental health education and expanded the beneficial scope of mental health education, which is favored by students with good effect. But this mode does not take the personality development of most students into account, ignoring the role of mental health education in promoting the healthy development of the majority of students. In order to improve the deficiencies exist in original mental health education, the present study attempts to carry out group 
psychological counseling among freshmen with positive psychology as the leading concept.

\section{THEORETICAL FOUNDATION}

Positive psychology is the science dedicated to the study of human's development potential and virtues. Positive psychology is a psychological movement rising in the west in early 21st century. Positive psychology is significantly different from the previous psychological research. Positive psychology pays close attention to people's positive traits and qualities. In the framework of positive psychology, we can find a complete figure to describe and understand the beautiful life. Positive psychology research can be divided into three themes:

- positive subjective experience (happiness, pleasure, gratitude, achievement);

- positive personal traits (personality strength, talent, interest);

- positive institution (family, school, community and society).

Mental health under the perspective of positive psychology is the personal subjective experience. Objective conditions are factors that affect mental health, and there are less negative factors and more positive factors for mental health.

Students are in a stage of rapid development and maturity. Every college student has a great potential for development and the strong motivation of success, happiness and development. Positive psychology focuses on students' positive growth, potential development, and can help students generate the positive aspirations, interests, beliefs, and promote college students' healthy growth. Therefore, the application of concept of positive psychology in freshmen's psychological health education is of positive significance.
Group counseling is an important way to provide psychological assistance and guidance in group situations. It prompts group members' adaptation to life, self-understanding, self-exploration and self-acceptance through internal interaction within the group, as well as careful observation, careful study and diligent experience in order to adjust and improve relationships with others, and learn the new attitudes and patterns of behavior to help others.

\section{RESEARCH PROCESS}

This study attempts to apply the concept of positive psychology to the freshmen group psychological counseling. To investigate the role of group psychological counseling in promoting freshmen's mental health through conducting group psychological counseling.

In this study, after the mental health test on freshmen, select two administrative classes without significant difference as subjects. Conduct group psychological counseling for Class A while Class B class does not participate in group psychological counseling. Class A participates in positive group psychological counseling which lasts for 6 weeks and is divided into 6 themes. Related activities are conducted around the theme once a week 90 minutes each time. Class B does not participate in group psychological counseling within the 6 weeks "Table I", “Table II".

TABLE I. CONTRAST OF SUbJeCtS’ BASIC Situation

\begin{tabular}{|c|c|c|c|c|c|}
\hline & \multicolumn{2}{|c|}{ Subject of Group A } & \multicolumn{2}{|c|}{ Subject of Group B } \\
\hline & & $\begin{array}{c}\text { Number } \\
\text { of } \\
\text { people }\end{array}$ & Percentage & $\begin{array}{l}\text { Number } \\
\text { of people }\end{array}$ & Percentage \\
\hline \multirow{2}{*}{ Gender } & Male & 12 & $40 \%$ & 14 & $46.7 \%$ \\
\hline & Female & 18 & $60 \%$ & 16 & $53.3 \%$ \\
\hline Total & & 30 & $100 \%$ & 30 & $100 \%$ \\
\hline
\end{tabular}

TABLE II. Contrast of Number of People Whose SCL-90 Score Have EXceEded the StANDARd of the Two Groups

\begin{tabular}{|c|c|c|c|c|c|c|c|c|c|c|c|}
\hline & $\begin{array}{l}\text { Averag } \\
\text { e Score }\end{array}$ & $\begin{array}{c}\text { Somatiz } \\
\text { ation }\end{array}$ & $\begin{array}{l}\text { Compulsive } \\
\text { Symptoms }\end{array}$ & $\begin{array}{c}\text { Sensitive of } \\
\text { Human } \\
\text { Relationship }\end{array}$ & $\begin{array}{l}\text { Depres } \\
\text { sion }\end{array}$ & Anxiety & Hostility & Horror & Intolerance & Psychoticism & Other \\
\hline $\begin{array}{l}\text { Group } \\
\text { A }\end{array}$ & 139.2 & 3 & 14 & 10 & 6 & 4 & 6 & 2 & 7 & 6 & 5 \\
\hline $\begin{array}{l}\text { Group } \\
\text { B }\end{array}$ & 142.2 & 4 & 12 & 12 & 7 & 7 & 5 & 7 & 8 & 5 & 6 \\
\hline
\end{tabular}

Difference test of total scl-90 score of the two groups of subjects "Table III".

TABLE III. INDEPENDENT SAMPLE TEST

\begin{tabular}{|c|c|c|c|c|c|c|c|c|c|c|}
\hline & \multicolumn{2}{|c|}{$\begin{array}{c}\text { Levene Test of } \\
\text { Variance Equation } \\
\end{array}$} & \multicolumn{7}{|c|}{ T Test of Mean Equation } \\
\hline & & \multirow[b]{2}{*}{$\boldsymbol{F}$} & \multirow[b]{2}{*}{ Sig. } & \multirow[b]{2}{*}{$t$} & \multirow[b]{2}{*}{$d f$} & \multirow{2}{*}{$\begin{array}{l}\text { Sig.(two } \\
\text { sides) }\end{array}$} & \multirow{2}{*}{$\begin{array}{l}\text { Difference of } \\
\text { mean value }\end{array}$} & \multirow{2}{*}{$\begin{array}{c}\text { Standard } \\
\text { error value }\end{array}$} & \multicolumn{2}{|c|}{$\begin{array}{l}\text { 95\% confidence interval of } \\
\text { difference }\end{array}$} \\
\hline & & & & & & & & & Lower limit & Upper limit \\
\hline \multirow[t]{2}{*}{ Total } & $\begin{array}{l}\text { Assume the variance } \\
\text { is equal }\end{array}$ & .028 & .868 & .262 & 58 & .795 & 2.967 & 11.341 & -19.735 & 25.668 \\
\hline & $\begin{array}{l}\text { Assume the variance } \\
\text { is not equal }\end{array}$ & & & .262 & 57.654 & .795 & 2.967 & 11.341 & -19.738 & 25.671 \\
\hline
\end{tabular}


It can be seen from the contrast of above two sets of data, there are significant difference of the two classes in terms of gender and mental health, which is in line with the requirements of researchers on subjects and conducive to conduct the research effectively.

This study only conducts group psychological counseling on Class A which lasts for 6 weeks and is divided into 6 themes. Related activities are conducted around the theme once a week 90 minutes each time.

In this study, the overall mentoring program is named as "Open a New Life". According to the characteristics of college students' psychological development, it includes six themes: First acquaintance; I'm great, too; Flower of my friendship; Optimism and hope; Life background; everybody can do something.

\section{Theme 1: First acquaintance.}

First, warm-up activities: Love at your fingertips. Objective: to activate the atmosphere and promote acquaintance. Operation: divide the students into two groups randomly, and form two cycles of internal and external ones, standing face to face. When the leader issues a "gesture" password, each member stretch out $1 \sim 4$ fingers to the opposite:

- one finger means "I do not want to know you now";

- two fingers means "I wish to have a preliminary understanding and a nodding acquaintance with you";

- three fingers means "I'm glad to know you, and want to know you further to be ordinary friends with you";

- four fingers means "I like you and want to be your good friends to share the joy and pain together with you".

when the leader issues a" movement "password, members shall make the appropriate action according to the following rules.

Second, circulated communication. Objective: to start a conversation and to be familiar with each other as soon as possible. Operation: use grouping method of warm-up activities, and communicate face to face for 2 minutes, and rotate the exchange objects to continue communication with new friends. Communication contents: self-introduction, hometown, biggest goal in college.

Third, group formation. Objective: to promote the formation of group cohesion. Operation: select leader within the group, discuss the team name, slogan and songs. Conclude group contract and regulate the behavior of group members.

\section{Theme 2: I'm great, too.}

First, warm-up activities: hit the loser. Objective: to strengthen the acquaintance between members. Operation: all members sit in a circle, select one student to hold a stick made up of newspaper. When the leader shouts a person's name, members at left and right sides of the one who has been called shall immediately stand up, or they shall receive a blow.
Second, self-portrait. Objective: to assist members to strengthen self-awareness and promote consciousness. Operation: members can draw themselves in any form following their own meaning. It can be specific and abstract. Members draw on their own paper, and then exchange and share within the group. Invite members to talk about their feelings within the group.

Third, advantage trade-off. Objective: to recognize their own advantages, deepen the treasure of their own advantages, and develop self-confidence. Operation: members write five of their most important qualities; and remove reject the factors that can be rejected, to leave only one at last. Discussion: whether the advantages that have been written are objective? Write the reason to reject each advantage, and how to carry forward their advantages.

\section{Theme 3: Flower of my friendship.}

First, warm-up activities: the wind blows. Objective: to activate the atmosphere and facilitate exchanges. Operation: all members sit in a circle, with the total stools less than the total people by one. One student acts as the host and issues the password: Siberian wind is blowing! The others ask: Where does it blow to? The host: Blow to the people who wear glasses. So, all the people who wear glasses must change seats, all others shall grab stools together with the host. One student will unable to get a stool, and then he/she shall continue to act as host.

Second, flower of my friendship. Objective: to understand the status of contacts, and learn to take the initiative to contact. Operation: draw the flower of friendship with ten petals, and paint the aspects they perform well into red. Show and exchange within the group. Explain the aspects they need to strengthen, and how to work.

Third, make compliment. Objective: to learn to appreciate and praise as well as promote mutual acceptance. Operation: members of the group sit in a circle with one sitting in the middle, and the remaining members take turns to say their strengths. All members take turns with each to experience one time and share their feelings.

Theme 4: Optimism and hope.

First, warm-up activities: grasp fingers. Operation: all members sit in a circle, extending their right palms down; then extend their left index fingers, withstanding the next one's palm. Leader designs a passage, when a certain word appears, the members shall grasp finger quickly, at the same time, get out the ginger that withstands other people's palm.

Second, my aspirations and goals. Objective: to express their aspirations and pursues, review dissatisfaction toward their self-condition, convert positive into negative. Operation: write down the various current aspirations and goals. Classify aspirations and objectives for their own and others; is it easy to share and change themselves or to change others? How to do in daily life?

Third, ties in heart. Objective: to promote member integration. Operation: all members sit in a circle hand in hand, and remember whose hands are in their left and right hands. Release the hands and walk around in the circle. When the 
leader calls stop, stand still and grasp the original hands, and return to the original state without releasing the hands. Share the feelings.

Theme 5: Life background.

First, warm-up activity: seven up. Objective: to enliven the atmosphere. Operation: all members sit in a circle and count off in turn, when the last number of the figure is 7 or multiple of 7, this member shall clap his/her hands without speaking out the figure.

Second, life background. Objective: to clarify selfevaluation, analyze the influence using clarification technology to promote changes in self-evaluation. Operation: consider their own uniqueness, and express it in the form of "I'm a () person." Evaluate each statement, and classify it into positive or negative. Discuss what factors have contributed to their evaluation? What changes are expected for negative items?

Third, drift bottles. Objective: to help each other with brainstorming, and promote settlement of difficulties. Operation: group members sit in a circle, with down their troubles with the note of same specifications anonymously. Put the note into drift bottles, and after the completion of all notes, select randomly, write down the answers to the questions on the note. Share and exchange their answers, and discuss a better solution.

\section{Theme 6. Everybody can do something}

First, warm-up activity: human chair. Objective: to activate the atmosphere, and cultivate team support and trust. Operation: all members form a circle, with hands putting on shoulders of the person in front, toes pressing against the heels of the front people, and slowly sit down on the legs of the people behind.

Second, Everybody can do something. Objective: selfappreciation, self-discovery, face and challenge with courage. Operation: recall the successful experience, sum up experience, and share the successful experience with team members; draw up a certificate of merit according to their expertise and successful experience, grant awards to themselves and shout out prize announcement. Share feelings.

Third, about the future. Objective: to encourage members face the future; Operation: depict the future in the form of paintings. Exchange and share.

Fourth, summary. Review the entire group counseling process.

After the implementation of group counseling, reuse scl-90 scale to test the subjects in both groups. Test results are as follows "Table IV".

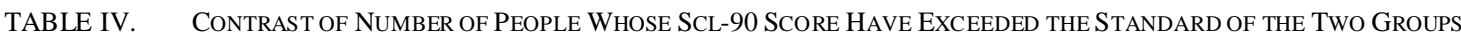

\begin{tabular}{|c|c|c|c|c|c|c|c|c|c|c|c|}
\hline & $\begin{array}{l}\text { Average } \\
\text { Score }\end{array}$ & $\begin{array}{c}\text { Somatiza } \\
\text { tion }\end{array}$ & $\begin{array}{l}\text { Compulsive } \\
\text { Symptoms }\end{array}$ & $\begin{array}{c}\text { Sensitive of } \\
\text { Human } \\
\text { Relationship }\end{array}$ & $\begin{array}{l}\text { Depres } \\
\text { sion }\end{array}$ & Anxiety & Hostility & Horror & $\begin{array}{c}\text { Intolera } \\
\text { nce }\end{array}$ & Psychoticism & Other \\
\hline $\begin{array}{l}\text { Group } \\
\text { A }\end{array}$ & 119.3 & 2 & 7 & 1 & 0 & 2 & 1 & 2 & 1 & 1 & 3 \\
\hline $\begin{array}{l}\text { Group } \\
\text { B }\end{array}$ & 136.6 & 3 & 5 & 7 & 6 & 6 & 5 & 4 & 3 & 6 & 6 \\
\hline
\end{tabular}

Contrast the previous test data and subsequent test data of Group A, with the results as listed below "Table V".

TABLE V. INDEPENDENT SAMPLE TEST

\begin{tabular}{|c|c|c|c|c|c|c|c|c|c|c|}
\hline & \multicolumn{2}{|c|}{$\begin{array}{c}\text { Levene Test of } \\
\text { Variance } \\
\text { Equation }\end{array}$} & \multicolumn{7}{|c|}{ T Test of Mean Equation } \\
\hline & & \multirow[b]{2}{*}{$\boldsymbol{F}$} & \multirow[b]{2}{*}{ Sig. } & \multirow[b]{2}{*}{$t$} & \multirow[b]{2}{*}{$d f$} & \multirow{2}{*}{$\begin{array}{l}\text { Sig. (two } \\
\text { sides) }\end{array}$} & \multirow{2}{*}{$\begin{array}{l}\text { Difference of } \\
\text { mean value }\end{array}$} & \multirow{2}{*}{$\begin{array}{c}\text { Standard error } \\
\text { value }\end{array}$} & \multicolumn{2}{|c|}{$\begin{array}{l}95 \% \text { confidence interval of } \\
\text { difference }\end{array}$} \\
\hline & & & & & & & & & \begin{tabular}{|l|} 
Lower limit \\
\end{tabular} & Upper limit \\
\hline \multirow[t]{2}{*}{ Total } & $\begin{array}{l}\text { Assume the variance } 1 \\
\text { is equal }\end{array}$ & 0.252 & .002 & 2.573 & 58 & .013 & 22.83333 & 8.87349 & 5.07111 & 40.59556 \\
\hline & $\begin{array}{l}\text { Assume the variance } \\
\text { is not equal }\end{array}$ & & & 2.573 & 46.143 & .013 & 22.83333 & 8.87349 & 4.97341 & 40.69326 \\
\hline
\end{tabular}

According the contrast results, $\mathrm{p}=0.02<0.05$, it can be considered that significant difference exists between the previous test data and subsequent test data of Group A.

Contrast the previous test data and subsequent test data of Group B, with the results as listed below "Table VI". 


\begin{tabular}{|c|c|c|c|c|c|c|c|c|c|c|}
\hline & \multicolumn{2}{|c|}{$\begin{array}{c}\text { Levene Test of } \\
\text { Variance } \\
\text { Equation } \\
\end{array}$} & \multicolumn{7}{|c|}{ T Test of Mean Equation } \\
\hline & & \multirow[b]{2}{*}{$F$} & \multirow[b]{2}{*}{ Sig. } & \multirow[b]{2}{*}{$t$} & \multirow[b]{2}{*}{$d f$} & \multirow[b]{2}{*}{ Sig. (two sides } & \multirow{2}{*}{$\begin{array}{l}\text { Difference of } \\
\text { mean value }\end{array}$} & \multirow{2}{*}{$\begin{array}{c}\text { Standard error } \\
\text { value }\end{array}$} & \multicolumn{2}{|c|}{$\begin{array}{l}\text { 95\% confidence interval of } \\
\text { difference }\end{array}$} \\
\hline & & & & & & & & & Lower limit & Upper limit \\
\hline \multirow[t]{2}{*}{ Total } & $\begin{array}{l}\text { Assume the variance. } \\
\text { is equal }\end{array}$ & .000 & 1.000 & .214 & 58 & .831 & 2.56667 & 12.00085 & -21.45565 & 26.58898 \\
\hline & $\begin{array}{l}\text { Assume the variance } \\
\text { is not equal }\end{array}$ & & & .214 & 57.918 & 831 & 2.56667 & 12.00085 & -21.45637 & 26.58971 \\
\hline
\end{tabular}

According the contrast results, $\mathrm{p}=1.0>0.05$, it can be considered that no significant difference exists between the previous test data and subsequent test data of Group B.

\section{DISCUSSION}

According to the above comparison test results, it can be found that the previous test data and subsequent test data of group A have significant differences, revealing that most of the students' mental health status has improved significantly through group counseling. Subsequent test data of Group B shows that during the study period, students' mental health is improved, but there is no significant difference between previous test data and subsequent test data. The change of subjects' mental health in Group B may be the result of their normal development and further adaptation to the university life. It can be seen from the comparison of two sets of data that the enhancement of mental health of students in the group A is relatively obvious, which can prove that the group counseling method used in the study plays a significant positive role in promoting students' mental health.

At the end of the counseling, make random interview to students from Group A to learn students' change. Students say that "they are very happy, there is a lot of fun"; "they have more understanding toward themselves, and they are more confident"; "they have learned how to communicate with others within the group, and now they have many good friends."

From the overall results, the present study has basically achieved the desired objectives. Cultivate students' positive self-awareness through "I'm great, too"; cultivate students' positive relationships through "Flower of my friendship"; cultivate students' positive emotions through "Optimism and hope"; cultivate students' positive self-evaluation through "Life background," and cultivate students' positive yearning for the future through the "Everybody can do something ".

\section{REFERENCES}

[1] Gong Huixiang. Practice and research of group counseling in the first edition of June, 2010.

[2] Wang Yongduo. Research on the intervention of mental health in agronomy major through the group psychological counseling. East China Normal University.2011.
[3] Zhu Xiaogen. The application of group counseling in mental health education of freshmen in Vocational College. Vocational Education.2012 (30). 